DOI 10.14746/ssp.2020.4.3

\author{
Eliza KanIA
}

Brunel University London

ORCID ID: 0000-0002-9635-9354

\title{
Demanding the Impossible: the Precariat, Social Outrage and Anti-austerity Movements
}

\begin{abstract}
The article analyses major legacies of anti-austerity movements since 2011: Indignados/as and Occupy Wall Street (known also as the movements of the precariat). Based on the author's research developed in her book: The precariat and the process of precarisation of labour - new directions of global socio-economic changes (original title: Prekariat i proces prekaryzacji pracy - nowe kierunki zmian społeczno ekonomicznych $w$ świecie), the article summarises the most significant outcomes of these movements' activities and demands, in four primary dimensions: identity, social awareness, organisation and politics. The author also answers the question of whether, in the course of anti-austerity movements' activities, a new social group - the precariat - gained political subjectivity.
\end{abstract}

Key words: the precariat, austerity, anti-austerity movements, social movements, economic crisis of 2008, Indignados/as, Occupy Wall Street

Tovernments of countries affected by the economic crisis of $2008+$ ity policies (Blyth, 2015). These actions were simultaneously accompanied by massive bailouts for banks and other financial institutions, which had been responsible for the crisis. This sparked the mass public protests that started in 2011. The massive social outrage led to the emergence of two social movements: Indignados/as ${ }^{1}$ (also known as the M-15 or Movimento 15-M) in Spain and Occupy Wall Street in the US, and internationally. In 2011, over eight million people participated in the protests in Spain alone.

This wave of protests is considered the most visible manifestation of the precariat (Standing, 2011) - a newly constructed social category. The precariat is a consequence of the global transformation of the system of labour organisation, which intensified in the 1970s and the following decades (Ros-

${ }^{1}$ Indignados translates from Spanish as the outraged (masculine form). I decided to use the spelling of Indignados/as because it includes both masculine and feminine gender (-os-masculine form, - as feminine form) and thus better reflects the spectrum of people creating this movement. 
er, Ortiz-Ospina, 2016). The most significant shifts in this area were: the erosion of the traditional working class, the spread of flexible employment, increasing the scale of immaterial labour, work automation, the privatisation of common goods and public services, and some effects of globalisation.

\section{Basic concepts}

After almost two decades of initial deliberations on the process of the precarisation of labour, in 2011 a British scientist, Guy Standing, initiated a broader discussion on the precariat in his newly published book (Standing, 2011). He claims that the precariat (a hybrid of the proletariat, and the word precarious - describing something fragile, that needs to be taken care of) is a social class in the making - in statu nascendi. It is the outcome of the post-Fordist expansion of insecure and flexible employment and outsourcing. The most significant factors that help to characterise the precariat are (1) several forms of labour-related insecurities, such as employment insecurity, income insecurity or representation insecurity, and (2) a lack of a secure work-based identity (Standing, 2011, p. 10). Moreover, Standing points out that the precariat suffers from anger, anomie, anxiety, and alienation. Alienation appears when one considers his/her life meaningless and when what a person does serves no purpose that is valued or respected (Standing, 2014, p. 66). The awareness that essential needs are not being satisfied causes anger. Knowing that the position of a precarian may worsen drastically at any moment is a source of anxiety. Anomie is defined as apathy, resulting from a "feeling of passivity born of despair" (Standing, 2011, p. 20). Standing also refers to relative deprivation and status discord (Standing, 2011, p. 10). The sense of relative deprivation in the context of the precariat means comparing one's situation on the labour market to prior generations (however, after superficial analysis, and in the case of the most economically developed countries, their situation may seem more stable). Moreover, people with relatively high level of education, who are forced to accept a job below their expectations and qualifications can feel status discord: a sense of unused potential and wasted opportunities. Standing argues that the precariat also lacks social memory. The notion of the precariat most often refers to younger generations of people who are educated but have no certain futures. They are either unemployed or employed on so-called "zero-hour contracts," often balancing on the verge of poverty. 
Other researchers who have developed the concept of the precariat are: Judith Butler (2011), Zygmunt Bauman (2011), Franco Berardi (2009), Enda Brophy and Grieg de Peuter (2007), and others. Scholars also deliberated on the roots of the precariat and the process of the precarisation of labour (Gorz, 1982; Bourdieu, 1998; Negri, Hardt, 2000, 2004, 2009 and others). Standing $(2014,2019)$ expanded his theories in many other works and studies.

The analytical framework put forward in this article also refers to the conceptual toolkit proposed by Guy Standing (2014b, p. 10) outlining the phases in which the precariat attained political subjectivity. Standing distinguished three stages: (1) collective recognition, (2) representation, and (3) political re-engagement. Collective recognition is the moment when people who belong to a given group search for the foundations of a common identity. Standing recognises the anti-austerity protests of 2011 as a stepping stone for the precariat to enter this phase (Standing, 2014b, p. 10). However, in my opinion, this phase started earlier, i.e. in the early 2000 s, during the activity of smaller precarity-related social movements (e.g. EuroMayDay). Simultaneously, academic research on the subject started, and basic theorisations of the central concepts were outlined. The massive social protests of the Indignados/as and Occupy Wall Street movements in 2011 can be considered marking the closure of the first phase and the commencement of the second phase (representation). Standing defines this phase as the ability to create and use a collective (and individual) voice that can make a real influence on state institutions and political actors and can initiate global action. It is necessary to develop specific demands to move to this phase. The third phase, political re-engagement, means attaining political subjectivity. In this article, I also refer to the conceptual model created by Marcus Holdo (2019), which analyses political games between elites and social movements. Holdo described four major possible variants of movement-elite interactions: being part of a cooptation strategy (continued contestation, elite domination), or a cooperative strategy (movement domination, conditional cooperation).

I aim to analyse the legacy of the Indignados/as and Occupy Wall Street movements and to answer the question of whether their demands transferred into the world of politics. My initial assumption is that the ideas and demands of these movements moved the precariat to the phase of political re-engagement. The research methods I use in this article are primarily the genetic explanation method, discourse analysis, and comparative method. 


\section{The chronology of the protests: Spain}

The economic prosperity of Spain deteriorated drastically in 2008. Until then, the country had been experiencing an economic boom, practically since the late 1980s (Etxezarreta, 2011, p. 3). In February 2011, the society was struggling with an unemployment rate of 22 per cent, and 47 per cent in the case of youth unemployment (Castells, 2013, p. 115). More than 54 per cent of Spaniards aged 18-34 still lived with their parents, due to the lack of jobs and affordable housing (Castells, 2013, p. 131). Furthermore, the socialist government, under pressure from Germany and the International Monetary Fund, implemented austerity measures, especially in the areas of health, education and social welfare. The burden of reforms fell primarily on Spanish taxpayers, while the banks and the financial sector institutions did not face any responsibility (Hughes, 2011, p. 409). The fact that for years Spaniards witnessed numerous corruption scandals fuelled anxiety and distrust towards political parties (Castells, 2013, p. 115). A conceptual inspiration for the protesters was the book by WWII French resistant movement member, Stephane Hessel (2011), Indignez-vous! (Time for Outrage!), published in 2010 . Hessel encouraged the younger generations to express their outrage and to fight for the improvement of their situation.

Initially, the Indignados/as movement was closely related to the Democracia Real Ya (True Democracy Now) protest campaign, and several other organisations. The group created a slogan summarising their demands: "Democracia Real Ya: We are not products in the hands of politicians and bankers" (Romanos, 2013, p. 206). They also expressed anger and called for unity and change in their Manifesto (2011). From March 2011 onwards, people were encouraged to go out into the streets and express their indignation. The suggested date was 15 May 2011 - a week before the local and regional elections (Castells, 2013, p. 116).

On 15 May 2011, over 50,000 people protested on the streets of Madrid, 20,000 on the streets of Barcelona, and 10,000 in Valencia. Also, fifty other cities across Spain joined the protests (Castells, 2013, p. 117). Some of the protesters, both in Madrid and Barcelona, started setting up acampadas - long-term camps occupying the public space. Another significant event was the march to Madrid from many cities all over Spain planned for 22 July 2011. It resulted in a demonstration involving 250,000 people, who gathered at Puerta del Sol on 23 July. These demonstrations gained global interest due to the article (and a first-page excerpt) published in The Washington Post on 19 May 2011, entitled "A spring of frustration" (Castells, 2013, p. 118). 
Later on, the implementation of Angela Merkel's ultimatum by the Spanish government sparked another wave of demonstrations that began on 15 October 2011. Over 500,000 people protested in Madrid alone, in Barcelona $-400,000$ people. This wave of anti-austerity protests reached over 900 cities and 82 countries around the world (Castells, 2013, p. 120). At the peak of its activity, 80-88 per cent of Spanish society identified with the movement (The Economist, 2011; El Pais, 2011). One year after the escalation of the protests, on 17 May 2012, the movement enjoyed the support of 68 per cent (Sampedroa, Lobera, 2014, p. 63).

\section{The chronology of the protests: the United States}

In the United States, after 2008, the government was focused on saving the financial system, which was later spotted by the protesters and reflected in the slogan "Banks Got Bailed Out - We Got Sold Out" (Gould-Wartofsky, 2015). The Indignados/as movement was an inspiration for the protesters in the US, and European and North-African immigrants played a significant role in establishing the Occupy Wall Street movement (Romanos, 2013).

After a series of smaller activist campaigns, initiated through the Adbusters platform, on 17 September 2011, 800 to 2,000 demonstrators (depending on estimates) marched through the business district of Manhattan (Earle, 2012). The protesters established a peaceful camp in Zuccotti Park (also known as the Liberty Plaza), near Wall Street. They popularised the slogan "We are the $99 \%$," which referred to socioeconomic inequalities and people's opposition to the world's financial elite. The breakthrough took place on 15 October 2011, when people were protesting in 951 cities, in 82 countries around the world, and 50,000 people gathered in Manhattan alone (Castells, 2013, p. 120). At the time of its most significant activity, the Occupy Wall Street movement enjoyed public support of 50 per cent, but a few months later, it dropped to 33 per cent (Earle, 2012, p. 5).

\section{Major demands}

Some critics claimed that both movements failed to create a coherent political programme. I argue that they constituted a range of transparent 
demands, which got through to the public consciousness, and some of the demands - to the political sphere.

The demands of the Indignados/as movement activists oscillated between (1) rejecting the privileged position of bankers and speculators, and (2) decreasing social and economic inequalities. They also called for (3) the nationalisation of banks instead of bailing them out, and they proposed (4) taxing the wealthiest citizens and corporations. Austerity policy was also invariably found to be controversial (Manifesto, 2011). People also protested against (6) "the seizure and eviction of elderly people and vulnerable families" (Castells, 2011, p. 126). The group "Youth without a future" emphasised the importance of (7) the right to education, work, housing and egalitarian access to culture (Vilaseca, 2014, p. 121). Protesters criticised (8) broadly understood consumerism ("most citizens are cogs in the machine for the enrichment of a minority that does not even know our needs") (Manifesto, 2011). They openly questioned the pursuit of profit and constant economic growth and discussed the need to redefine capitalism.

The critical demands of the Occupy Wall Street protesters included, among other things: fighting unemployment, overseeing financial speculation, an audit of the Federal Reserve, and solving the crisis on the housing market. They also insisted on the need for supervising currency speculation, defending the right to collective bargaining and trade union rights, and reducing income inequality. Occupy Wall Street opposed job outsourcing and highlighted the urgency of reforming the system of political parties' financing. They objected to the revocation of the Supreme Court's decision on corporate personhood and put forward many other postulates that often involved pacifism and ecology (Castells, 2013, pp. 184-185). Well-known intellectuals as Slavoj Žižek, Judith Butler and Michael Moore also supported the protests.

Butler (2011b) also contested the allegation that the movement was not specific enough to create a coherent program, saying:

"People have asked, so what are the demands that all these people are making? Either, they say, there are no demands, and that leaves your critics confused. Or they say: that demands for social equality and economic justice are impossible demands. And impossible demands are just not "practical." But we disagree. If hope is an impossible demand, then we demand the impossible. If the right to shelter, food and employment is impossible demands, then we demand the impossible. If it is impossible to demand that those 
who profit from the recession redistribute their wealth and cease their greed, then yes, we demand the impossible!"

\section{Major outcomes}

To analyse and summarise the outcomes of the activities of the Indignados/as and Occupy Wall Street movements, I decided to focus on four dimensions: (1) identity, (2) social awareness, (3) organisation, and (4) politics.
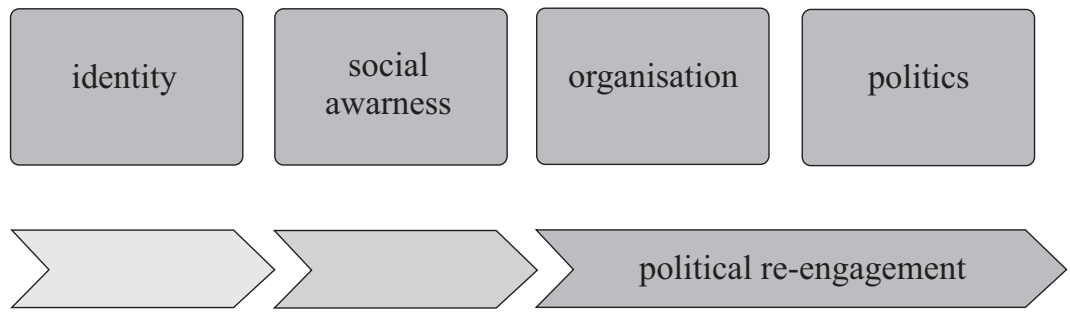

Illustration 1. The legacies of the movements: four dimensions

The profound legacy of both movements is the design of a new conceptual toolkit and the foundations of a new collective identity. The slogan "We are the 99\%" and even the Guy Fawkes mask - often used during the protests - have gained a symbolic status. The popularisation of the slogan "We are the 99\%" is considered one of both movements' most significant successes. It helped to transfer the reflection on social and economic inequalities to public debates (Anderson, 2011). This slogan's essential role was to draw attention to how 1 per cent of the financial elite in recent decades had deprived most of the population of economic benefits (Earle, 2012, p. 16) and how to communicate this. The $99 \%$ idea "managed to do something that no one has done in the United States since the Great Depression: revive the concept of social class as a political issue" (Graeber, 2016). Another identity-related effect was the emergence of a new sociological type - a graduate with no future. In the case of both movements, the majority of protesters were college students or unemployed and frustrated graduates (Castells, 2013, p. 120).

Initially, mainstream media outlets either showed no interest in the protests or were sceptical about them. Over time, the movements' activi- 
ties began to catch the attention of the most popular media outlets and broader audiences. The most spectacular and symbolic displays of the movements' activities were two publications, which appeared in "Time" and "The Economist." Each year (as part of a tradition going back to 1927) "Time" editors pick the "person of the year" to honour a person, group of people, idea or object that, for better or for worse, exerted the most significant impact on events in a given year (Time, 2012). The person of the year in 2011 was The Protester (an anonymous, universal figure). The "Time" editors highlighted the global nature of the demonstrations, saying: "from the beginning of the Arab Spring, we devoted many resources to telling the history of this part of the world. We also watched the germ of protest spread through Europe and then America" (Stengel, 2011). In June 2013, the conservative-liberal "The Economist" also used its cover to present a historical tableau of four landmark moments and places where universal history took place (The Economist, 2013). The tableau included a reference to the 2011 wave of protests. The appearance of the Indignados/as and Occupy movements in the mass social consciousness has led to many innovative discourses and points of reference concerning the criticism of contemporary capitalism and societies' condition (Mason, 2011).

The Indignados/as and Occupy Wall Street movements' organisational dimension includes acampados - protesters' camps organised to occupy public space. This method of protesting was considered reasonable in terms of deliberative democracy mechanisms. Such demonstrations in the public area created an agora for a more precise presentation of the activists' slogans and demands. The camps were "the basis of a countersociety that made dreams of real democracy come true" (Castells, 2013, p. 165). Another critical organisational aspect was the horizontal, leaderless approach to hierarchy. It is rooted in anarchist traditions, with their aversion to traditional political institutions, and some negative experiences of veterans of social movements (Greaber, 2011). Researchers also highlighted the high female representation during the protests, and some even stated that in the 21st century, the archetypal leader of such movements is a young, educated female activist. However, it was mainly young men who could afford long-term, full-scale occupation of space in tent towns, due to the lack of (or a different approach to) family or professional obligations (Castells, 2013, p. 137).

Additionally, scholars and researchers have been discussing and developing solutions and demands aimed at eliminating the negative con- 
sequences of the process of precarisation of labour, such as (1) universal basic income, (2) a financial transaction tax, a "Robin Hood" tax, and others, (3) sovereign wealth funds, (4) a global capital tax, as well as (5) the redefinition of working time, and (6) the revival of the idea of common goods and others (more: Collins, 2008; Gregg, 2009; Standing, 2014, 2014c; Piketty, 2015; Al-Hassan, Papaioannou, 2013, and others).

\section{The anti-austerity movements of 2011: the political dimension}

The Indignados/as and Occupy Wall Street movements created a new space in the political debate. The focus on debating debt and deficit shifted to the labour market, society and inequalities. The idea of the 1 per cent opposing the majority 99 per cent even made it into Barack Obama's presidential campaign in 2012 and, to a much greater extent, into Bernie Sanders's campaign three years later (Blow, 2013).

Noam Chomsky pointed out that one of the most tangible influences that the Occupy Wall Street movement had had on politics, at the initial phase of its activity, was the adoption of the New York Resolution No. 1172 by the City Council (Chomsky, 2013). The document opposed the idea of "corporate personhood," which translates into the possibility of the open funding of political factions by transnational corporations and business lobbies. Other cities (Los Angeles, Albany, Oakland and Boulder) have also implemented similar solutions (McCann, 2012).

The political influence of the Indignados/as movement is considered more significant. The movement's priority was to open the political scene in Spain, dominated by two parties: the Spanish Socialist Workers' Party and the Conservative-Liberal People's Party (Castells, 2013, p. 140). Activities of the Indignados/as movement shifted the focus from politics to meta-politics, promoting new approaches to democracy. The political space had also opened up for parties and fractions who seek to reduce social inequalities. This political vacuum was filled by the Podemos party, which stems directly from the Indignados/like movement.

\section{Political re-engagement}

I argue that the Spanish Podemos party and Bernie Sanders, with the left-wing of the US Democratic Party, are the most vivid examples of the 
transfer of protesters' demands into the political scene, thus entering the phase of political re-engagement.

Podemos, "the party of precarians" (Rebelya, 2015), has its roots directly in the Indignados/as movement. The party was founded on 17 January 2014 (Flesher Fominaya, 2014). Initially, lecturers of sociology, philosophy and political sciences who had formerly been involved in the movement led the party. Pablo Iglesias, who has a $\mathrm{PhD}$ in political science and gained popularity as a presenter in a TV political debate, became the leader of Podemos (Stobart, 2014).

Four months after its establishment, the party won 7.98 per cent of votes in the elections to the European Parliament on 25 May 2014 - came fourth in the country (Stasiński, 2014). In the parliamentary elections of 2015, Podemos activists gained the support of 19.7 per cent and became the third power in parliament (Tremlett, 2015). After failed negotiations to form a coalition government, another parliamentary election was held on 2 May 2016, in which the electoral coalition of Podemos and other left-wing Unidos Podemos groups gained the support of 24.5 per cent and remained the third force in the Spanish parliament. In the general elections on 28 April 2019, the Unidas Podemos coalition came fourth, with 21.2 per cent (Gutiérrez, Clarke, 2019). However, Prime Minister Pedro Sanchez (Spanish Socialist Workers' Party - PSOE) did not manage to form a coalition government. In the next election on 10 November 2019 - Unidas Podemos received fewer votes, 14.3 per cent (Gutiérrez, 2019). After nine months of a political deadlock, Podemos became part of the government coalition with the Spanish Socialist Workers' Party. Pablo Iglesias took over as deputy prime minister (Minder, 2020).

Several factors contributed to the success of Podemos. Apart from the popularity of Iglesias, the use of the specific tools, methods and demands of the Indignados/as movement prepared the grounds for this party (Flesher Fominaya, 2015). Initially, the focus was on creating local party circles (circulos), which served as local structures and thematic groups (dealing with issues such as economy, cooperatives, and feminism). Thanks to this, it was possible to isolate the core of the most engaged activists and to unify the ideological sphere (Nowak, 2015). The party's membership base grew to reach over half a million in 2019 (Nowak, 2015).

The core of Podemos's programme overlapped with political populism - defined by "two essential components: a critique of the elites and a claim to speak on behalf of a coherent and unified people" (Béland, 2019; Müller, 2016); and left-wing rhetoric, including opposing austerity policy, and 
fighting corruption on the Spanish political scene. The party's economic demands included several proposals to reduce the harmful effects of the process of the precarisation of labour. These proposals included raising the minimum wage, stimulating the economy by public spending, and introducing a 35-hour working week. However, the most radical ideas, such as a universal basic income or citizen debt audit, were abandoned (Nowak, 2016). The original program of Podemos consisted of six subgroups: economic democracy, social democracy, political democracy, civil democracy, international democracy, and regional and city proposals (Podemos, 2016).

Some elements in Podemos's agenda have been criticised for being unrealistic and populist (Garzón, 2015). Moreover, the United Left group (Izquierda Unida) suggested that Podemos' political program contained plagiarised ideas they had created. Other critics pointed out that Podemos, initially led by anti-political "romantics," systematically passed into the hands of "bureaucrats." Despite these concerns, Podemos certainly filled a vacuum on the Spanish political scene, stemming from the legacy of the Indignados/as movement (Flesher Fominaya, 2015).

The American Democratic Party faction that formed around Bernie Sanders included some demands of the Occupy Wall Street movement in its political agenda (Sanders Democrats 2016; Myerson 2016). Sanders is the only widely recognised American politician who openly admits to socialist views (which are not radical in comparison with the European socialist demands) (Sanders, 2016; Czerny, 2015). He used to be a congressman (1991-2007) and since 2007 has served as Senator of the State of Vermont. In May 2015, he became a Democratic Party primaries candidate, eventually losing to Hillary Clinton. Sanders also fought for a nomination in the presidential election in November 2020. He withdrew his candidacy in April 2020 (BBC, 2020).

Sanders' links and rapport with the Occupy Wall Street movement have been evident since 2011 (Sanders, 2011). He hoped that Occupy Wall Street's grassroots activism would transfer its energy into politics and shape its progressive political agenda. Indeed, the zeal of those involved in Occupy Wall Street powered Sanders's campaign (People for Bernie, 2016). The political program of Bernie Sanders highlighted the problem of increasing social inequalities and growing disproportions of income redistribution that arose after the economic crisis of 2008. It also highlighted poverty affecting children and overtime work for the minimum wage (Sanders, 2016). Sanders often used the Occupy movement slogan: "We are the 99\%" (Ye Hee Lee, 2015). His 2020 platform includ- 
ed similar demands on social and economic inequalities, but the focus was on a humanitarian immigration policy, refugee policy and the New Green Deal (Sanders, 2020).

Those sceptical about Sanders referred to his rhetorical pathos, irony and populism (The Economist, 2016). Sanders' critics also emphasise that his socialist views are rather declarative, and the solutions he proposes are not innovative (Lemon, 2020). Even though he has never won the Democratic Party nomination, Sanders managed to transfer and develop many demands of the Occupy Wall Street movement.

The progressive shift on the US political scene was also powered by four congresswomen of the Democratic Party elected to the US House of Representatives on 6 November 2018: Alexandria Ocasio-Cortez, Ilhan Omar, Ayanna Pressley and Rashida Tlaib - known as the Squad, due to their dynamic activities. Alexandria Ocasio-Cortez deserves special attention, as she was an organiser of the Sanders campaign in 2016, and she also often refers to the precarious situation of many young Americans. Born and raised in the Bronx, Ocasio-Cortez came from a Puerto Rican working-class family and worked as a waitress before taking up political activity. Her programme includes combating poverty in the US and the global climate crisis. Like Sanders, she advocates ideas such as "Medicare for All," a \$15 minimum wage and student loan cancellation. Currently, Ocasio-Cortez is one of the most recognisable figures on the political scene in the United States (Sullivan, 2019).

To some extent also the Greek Syriza and Diem 25 - movements established by Yanis Varoufakis within the European Union, the MeRa group in Greece, some postulates of the British Labour Party led by Jeremy Corbyn, La France Insoumise, and the Polish Razem party also adopted some ideas of anti-austerity movements of 2011 (Telek, 2018).

\section{Conclusions}

Referring to my preliminary hypothesis, I can confirm that the demands and ideas aroused during the activity of the Indignados/as and the Occupy Wall Street movements - the most visible manifestations of the precariat - have partially been transferred to the political sphere. They have led to the shift of focus in political debates to social and economic inequalities, provided a new conceptual toolkit, raised social awareness, and developed innovative organisational approaches. Transfers of these 
demands and even the engagement of the former movements' activists in politics took place in the case of the Podemos party, Bernie Sanders and the left-wing faction in the US Democratic Party, and a few other leftwing political parties and groups in Europe. This proves that the precariat entered the initial part of the third phase of its development: political reengagement (Standing, 2014b).

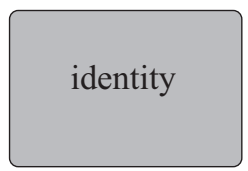

1. foudations of a collective identity

2. conceptual toolkit

3. new sociological type: a graduate with no future

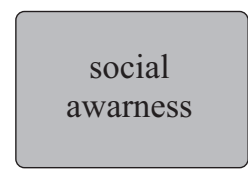

4. presence in mass media 5. new critical discourses

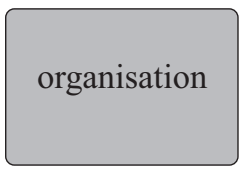

6. public space occupation (acampados)

7. horizontal, leaderless structure

8. feminisation

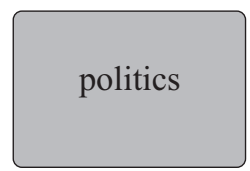

9. new space in the political debate 10. new space on the political scene (USA, Spain, others) 11. New York City Council Resolution 1172 12. shift of political support (Spain, US)

\section{political re-engagement}

Illustration 2. The major legacies of the movements: a summary

The relations between political elites and anti-austerity social movements can be described as conditional cooperation (Holdo, 2019). In this case, traditional political elites (understood as the political establishment operating in traditional political institutions) "seek out potential partners, who are not presently powerful movement leaders, and commit to empowering them in order to build a strategic relationship" (Holdo, 2019). Neither of the social movements described in this article currently exists, but their legacies are still valid and have been transferred to progressive political agendas and programmes.

\section{Bibliography}

Al-Hassan A., Papaioannou M., Skancke M., Chih Sung C. (2013), Sovereign Wealth Funds: Aspects of Governance Structures and Investment Management, "International Monetary Fund".

Anderson K. (2011), The Protester, “Time”, 14.12.2011, http://content.time.com/ time/specials/packages/article/0,28804,2101745_2102132_2102373-5,00. html, 10.03.2016. 
Bauman Z. (2011), O nie klasie prekariuszy, "Dziennik Opinii”, 14.07.2011, www. krytykapolityczna.pl, 10.07.2011.

BBC (2020), US election 2020: Meet the Democratic candidates vying to take on Trump, "BBC", https://www.bbc.co.uk/news/world-us-canada-47309795, 05.03.2020.

Béland D. (2020), Right-Wing Populism and the Politics of Insecurity: How President Trump Frames Migrants as Collective Threat, "Political Studies Review" $18 / 2$.

Berardi F. (2009), Precarious Rapsody. Semiocapitalism and the pathologies of the post-alpha generation, London.

Sanders B. (2016), Meet Bernie, "Bernie 2016", https://berniesanders.com/about, 15.05.2016.

Blow C. M. (2013), Occupy Wall Street Legacy, "The Washington Post”, 13.09.2013, http://www.nytimes.com/2013/09/14/opinion/blow-occupy-wall-street-legacy.html?_r=0, 17.03.2016.

Blyth M. (2015), Austerity, history of a dangerous idea, New York.

Bourdieu P. (1998), Acts of Resistance Against The Tyranny of the Market, New York.

Brophy E., de Peuter G. (2007), Immaterial Labour, Precarity, and Recomposition, in: Knowledge Workers in the information society, eds. C. McKercher, V. Mosco, Lexington Books.

Butler J. (2011), For and Against Precarity, "Occupy Theory”, December 2011, https://occupyduniya.files.wordpress.com, 12.07.2011.

Butler J. (2011b), If hope is an impossible demand, then we demand the impossible" - video, "Verso", 24.10.2011, http://www.versobooks.com/blogs/765if-hope-is-an-impossible-demand-then-we-demand-the-impossible-judithbutler-at-occupy-wall-street-video, 12.02.2016.

Castells M. (2013), Sieci oburzenia i nadziei. Ruchy społeczne w erze Internetu, Wydawnictwo Naukowe PWN.

Chomsky N. (2013), Occupy: Reflections on Class War, Rebellion and Solidarity, Occupied Media Pamphlet Series.

Collins J. (2008), The Specter of Slavery. Workfare and Economical Citizenship of Poor Women, in: New Landscapes of Inequality: Neoliberalism and the Erosion of Democracy in America, eds. M. Di Leonardo, J. L. Collins, B. Williams, SAR Press, Santa Fe.

Czerny I. (2015), USA: Socjalista Sanders największa niespodzianka początku kampanii prezydenckiej, "Gazeta.pl”, 3.07.2015, http://wiadomosci.gazeta.pl/, 15.05.2016.

Earle E. (2012), A brief history of Occupy Wall Street, Rosa Luxemburg Stiftung.

El Pais (2011), Majority of Spaniards support 15-M movement, "El Pais", 27.06.2011, http://elpais.com/elpais/2011/06/27/inenglish/1309152044_850210.html, 5.03.2016. 
Etxezarreta M. (2011), Boom and (deep) crisis in the Spanish economy: the role of the EU in its evolution, "Communication for 17th Workshop on Alternative Economic Policy in Europe", Vienna.

Flesher Fominaya C. (2014), "Spain is Different": Podemos and 15-M, "Open Democracy", 29.05.2014, https:/www.opendemocracy.net/can-europe-make-it/ cristina-flesher-fominaya/\%E2\%80\%9Cspain-is-different $\%$ E2\%80\%9Dpodemos-and-15m, 11.05.2016.

Garzón A. (2015), The Problem with Podemos, “The Jacobin”, 13.03.2015, https:// www.jacobinmag.com/2015/03/podemos-pablo-iglesias-izquierda-unida, 14.05.2016.

Gorz A. (1982), Farewell To The Working Class, An Essay On Post-Industrial Socialism, London.

Gould-Wartofsky M. (2015), The Occupiers. The Making of the 99 Percent Movement, New York.

Graeber D. (2016), Can Debt Spark a Revolution?, “The Nation”, 24.09.2012, http:// www.thenation.com/article/can-debt-spark-revolution/, 12.02.2016.

Greaber D. (2011), Occupy Wall Street's anarchist roots, “Al Jazeera”, 30.11.2011, https://www.aljazeera.com/opinions/2011/11/30/occupy-wall-streets-anarchist-roots/, 12.05.2016.

Gregg J. (2009), Job Guarantee: Evidence and Design, "Bristol University", September 2009, http://www.bristol.ac.uk/media-library/sites/cmpo/migrated/documents/jobguarantee.pdf, 12.04.2016.

Gutiérrez P. (2019), Spanish election 2019: full results, "The Guardian", 10 November 2019, https://www.theguardian.com/world/ng-interactive/2019/nov/10/ spanish-general-election-2019-live-results, 12.01.2020.

Hessel S. (2011), Time for Outrage: Indignez-vous!, London.

Holdo M. (2020), Power Games: Elites, Movements, and Strategic Cooperation, "Political Studies Review”, 18/2.

Hughes N. (2011), 'Young People Took to the Streets and all of a Sudden all of the Political Parties Got Old': The 15M Movement in Spain, "Social Movement Studies", no. 10/4.

Lemon J. (2020), Bernie Sanders is a democratic socialist not a communist, here's the difference, "Newsweek", 2.03.2020, https://www.newsweek.com/berniesanders-democratic-socialist-not-communist-heres-difference-1485478, 5.03.2020.

Manifesto (2011), "Democracia Real Ya", http://international.democraciarealya.es/ manifesto, 3.03.2016.

Mason P. (2011), Why It's Kicking Off Everywhere?, Verso Books.

McCann B. (2012), Cities, States Pass Resolutions Against Corporate Personhood, "CivSource", 4.01.2012.

Minder R. (2020), Pedro Sánchez Will Lead Modern Spain’s First Coalition Government, 7.01.2020, https://www.nytimes.com/2020/01/07/world/europe/spainpedro-sanchez-government.html, 10.01.2020. 
Müller J-W. (2016), What Is Populism?, University of Pennsylvania Press, Philadelphia, PA.

Myerson J. A. (2016), Building a Movement: From Occupy Wall Street to Bernie Sanders, "Telesur", 16.08.2016, https://www.telesurenglish.net/opinion/Building-aMovement-From-Occupy-Wall-Street-to-Bernie-Sanders-20160416-0023.html.

Negri A., Hardt M. (2000), Empire, Harvard University Press.

Negri A., Hardt M. (2004), Multitude: War and Democracy in the Age of Empire, New York.

Negri A., Hardt M. (2009), Commonwealth, Harvard University Press.

Nowak P. (2015), Podemos - oddolna energia idzie po władze, wywiad z Maciejem Szlinderem, "Strajk.pl”, 23.05.2015, http://strajk.eu/podemos-oddolna-energia-idzie-po-wladze, 12.05.2016.

People for Bernie (2016), http://www.peopleforbernie.com, 17.05.2016.

Piketty T. (2015), Kapitat XXI wieku, Warszawa.

Podemos (2016), Who we are?, "Podemos", http://podemos.info/conoce/?lang=en, 11.05.2016.

Rebelya (2015), Prekariat - “wyklęty lud” XXI wieku. Rozmowa z Guyem Standingiem, "Rebelya.pl”, 9.03.2015, http://rebelya.pl/post/7889/prekariat-wyklety-lud-xxi-wieku-rozmowa-z-guyem, 10.05.2016.

Romanos E. (2013), Collective learning processes within social movements. Some insights into the Spanish 15-M/Indignados movement, in: Understanding European Movements: New Social Movements, Global Justice Struggles, AntiAusterity Protest, eds. C. Flesher Fominaya, L. Cox, Routledge.

Roser M., Ortiz-Ospina E. (2016) Income Inequality, "Our World in Data”, University of Oxford, October 2016, https://ourworldindata.org/income-inequality, 12.01.2019.

Sampedroa V., Lobera J. (2014), The Spanish 15-M Movement: a consensual dissent?, "Journal of Spanish Cultural Studies", no. 1-2/15.

Sanders B. (2011), Senator Bernie Sanders on Occupy Wall Street \#whyoccupy, "YouTube", 21 October 2011, https://www.youtube.com/watch?v=9HSaZOSWfrU, 17.05.2016.

Sanders B. (2020), Issues, "Bernie Sanders", http://berniesanders.com, 21.01.2020.

Sanders Democrats (2016), http://sandersdemocrats.com, 15.05.2016.

Standing G. (2019), Plunder of the Commons, Penguin Books.

Standing G. (2011), The Precariat: The New Dangerous Class, Bloomsbury, London.

Standing G. (2014), A Precariat Charter: From Denizens to Citizens, Bloomsbury, London.

Standing G. (2014b), The precariat and the class struggle, "RCCS annual Review", https://journals.openedition.org/rccsar/585, 14.07.2014.

Standing G. (2014c), The Future of Work: The Precariat's Challenge, "Kulturaustausch online", March 2013, http://cms.ifa.de/?id=10098, 21.03.2016.

Stasiński M. (2014), Hiszpania - zwrot w lewo, "Gazeta Wyborcza”, 28.05.2014, http://wyborcza.pl/1,76842,16046386, 11.05.2016. 
Stengel R. (2011), A Year in the Making, "Time", 14.12.2011, http://content.time. com/time/specials/packages/article/0,28804,2101745_2102141,00.html, 14.03.2016.

Stobart L. (2014), Whatever happened to the Indignados? 2: Regime crisis, "Left Flank", 24.03.2014, http://left-flank.org/2014/03/24/whatever-happened-indignados-2-regime-crisis-uprisings/\#sthash.sQIloZj5.dpuf, 10.05.2016.

Sullivan K. (2019), Here are the 4 congresswomen known as 'The Squad' targeted by Trump's racist tweets, "CNN", 16.07.2019, https://edition.cnn. com/2019/07/15/politics/who-are-the-squad/index.html, 03.01.2020.

Sunkara B. (2016), Enter the Sanders Democrat, “Al Jazeera”, 8.02.2016, http:// america.aljazeera.com/opinions/2016/2/enter-the-sanders-democrat.html, 15.05.2016.

Telek A. (2018), Political precariat, “Open Democracy", 9.05.2018, https://www. opendemocracy.net/en/can-europe-make-it/political-precariat/, 14.03.2019.

The Economist (2011), Europe's most earnest protesters, "The Economist", 14.07.2011, http://www.economist.com/node/18959259; 5.03.2016.

The Economist (2013), June-July edition.

The Economist (2016), Bernie Sanders, the modern-day Mark Antony, "The Economist", 20 April 2016, http://www.economist.com.

Time (2012), Person of the Year: 75th Anniversary Celebration, New York.

Tremlett G. (2015), The Podemos revolution: how a small group of radical academics changed European politics, "The Guardian", 31.03.2015, http://www.theguardian.com/world/2015/mar/31/podemos-revolution-radical-academicschanged-european-politics, 11.05.2016.

Vilaseca S. L. (2014), The 15-M movement: formed by and formative of countermapping and spatial activism, "Journal of Spanish Cultural Studies", 15/1-2.

Ye Hee Lee M. (2015), Bernie Sanders's claim that 99 percent of new income is going to top 1 percent of Americans, "The Washington Post", 17.02.2015, https://www.washingtonpost.com/news/fact-checker/wp/2015/02/17/berniesanders-claim-that-99-percent-of-new-income-is-going-to-top-1-percent-ofamericans, 17.05.2016.

\section{Żądanie niemożliwego: prekariat, oburzenie i ruchy społeczne przeciw polityce cięć wydatków publicznych}

\section{Streszczenie}

Artykuł ten jest analizą głównych efektów działań ruchów społecznych, występujących przeciw wprowadzaniu polityki cięć wydatków publicznych (austerity policy), powstałych w 2011 roku: Indignados/as i Occupy Wall Street, zwanych także ruchami prekariatu. Na podstawie badań autorki opracowanych szerzej w książce: Prekariat 
i proces prekaryzacji pracy - nowe kierunki zmian społeczno ekonomicznych w świecie, w artykule podsumowano najważniejsze rezultaty działań i postulatów tych ruchów w czterech podstawowych wymiarach: tożsamości, świadomości społecznej, organizacji i w wymiarze politycznym. Autorka odpowiada również na pytanie, czy w toku tych działań nowa grupa społeczna - prekariat - uzyskała podmiotowość polityczną.

Slowa kluczowe: prekariat, polityka cięć wydatków publicznych, ruchy społeczne, kryzys ekonomiczny z 2008 roku, Indignados/as, Occupy Wall Street 